\title{
SAMUEL CHEON, The Exodus Story in the Wisdom of Solomon. A Study in Biblical Interpretation, Journal for the Study of the Pseudoepigrapha Sup- plement Series 23, Sheffield Accademic Press. England 1997, s. 153.
}

Recenzowana książka to przejrzana wersja rozprawy doktorskiej przedstawionej na Wydziale Teologicznym w Berkeley w roku 1994.

Początek dziejów Izraela wyznacza fakt Wyjścia z niewoli egipskiej. To historiozbawcze wydarzenie stanowi centralny temat Pięcioksięgu. W okolicznościach towarzyszących Wyjściu z Egiptu Izrael poznał, czyli doświadczył Boga. To głębokie doświadczenie stawało się potem przedmiotem wnikliwej refleksji i religijnej medytacji, a także punktem odniesienia dla współczesności. Boża interwencja $\mathrm{u}$ początków historii narodu izraelskiego była bowiem tak ważna i brzemienna w następstwa, że naród żył nią następne wieki, wspominając ją i widząc ją także w każdym wyzwoleniu. Dla późniejszych pokoleń Wyjście z Egiptu stanowiło wyidealizowany czas, wzorcowy okres dziejów, klucz do rozumienia historii i wizji przyszłości oraz podstawę do stawiania człowiekowi wymagań etycznych. Wątek Wyjścia podejmuje także Księga Mądrości. Czwarta część tej księgi poświęcona jest teologicznej zadumie nad Wyjściem Izraelitów z Egiptu, prawzorem i źródłem wszelkich działań Jahwe wobec Jego ludu.

Po krótkim wprowadzeniu $(11,2-4)$ przypominającym drogę przez pustynię, a będącym sumarycznym ujęciem wydarzeń, ukazuje mędrzec kilka momentów, świadczących o szczególnej opiece Boga nad potomkami Abrahama. Dobrodziejstwa te przeciwstawia plagom, jakich doświadczają Egipcjanie pojmowani jako ich polityczni i ideologiczni wrogowie.

Oto owe przeciwstawienia:

— pragnienie a woda (11, 1-14);

- głód a jego zaspokojenie (16, 1-4);

- umieranie a ocalenie (16, 5-14);

— grad i manna $(16,5-29)$;

— ciemności a światło $(17,1-18,4)$;

— śmierć a ocalenie $(18,5-25)$;

— utonięcie a przejście (19, 1-17).

Już pobieżna lektura opisu okoliczności Wyjścia zaczerpniętych z Pięcioksięgu, szczególnie z Księgi Wyjścia, jako źródła podstawowego, a zaadaptowanych w argumentacji przytoczonych w Księdze Mądrości, zwraca uwagę na czytelną tendencję zaszyfrowaną w modyfikacjach dokonanych przez hagiografa biblijnym materiałem źródłowym. Analizy tekstu Mdr 11, 1-14 i 16, 1-19, 22 rozdz. 2 (s. 2457) i rozdz. 3 (s. 68-107) wydobywają specyficzne dla autora sapiencjalnego tekstu hermeneutyczne procedury zastosowane wobec historiograficznych danych Pięcioksięgu. Rozdziały 4 i 5 (s. 108-124 i 125-149) syntetyzują owoce pracy. 
Celem udzielenia odpowiedzi na pytanie jak i dlaczego hagiograf interpretuje historię wyjścia, sięgnięto po ujęcie wydarzeń Exodusu we wcześniejszych księgach biblijnych, szczególnie w tradycji historycznej, oraz w literaturze judeohellenistycznej, czasowo bliskiej Sophia Salomonos — pismach Ezechiela Tragika, Artapana, Filona Aleksandryjskiego i Józefa Flawiusza. Swój introdukcyjny zamysł mędrzec osiąga przede wszystkim za pomocą poniższych dziewięciu zabiegów zogniskowanych wokół teologicznego opracowania początków własnego narodu.

Skoro punktem wyjścia dla hagiografa są skrypturystyczne przekazy na temat Wyjścia hagiograf zakłada, że Pismo Święte zawiera Objawienie i stąd można z niego ciągle na nowo coś wydobywać.

Wobec powyższego autor Księgi Mądrości, odnajduje nowe lub raczej głębsze znaczenie ogólnie znanym biblijnym wydarzeniom $(11,6-7 ; 17,7-8 ; 18,5)$.

Zawsze wprowadza antonomazje, naznaczone szeroką ogólnością zakresu znaczeń, gdyż:

— nie jest zainteresowany powielaniem historii Wyjścia;

- rozumie je parabolicznie - jako zapis egzemplów dobrego czy też złego życia, aktualnych w swoim przesłaniu dla każdego pokolenia $(19,22)$ szczególnie jego.

Mówi do odbiorcy znającego Pismo Święte, a zatem do współwyznawcy i (lub) do poganina o specjalnej erudycji, spotykanej w kulturze aleksandryjskiej.

Niemal konsekwentnie wydobywa z życia Izraelitów tylko pozytywne strony, dlatego przemilcza narzekanie na Pana i Mojżesza. Mroczne sceny z dziejów Izraela i cierpienia traktuje jako wystawienie współwyznawców przez Boga na próbę, a nie tylko jako karę za bunty na pustyni. Izraelici - uczestnicy Wyjścia odczytywani typicznie: jako sprawiedliwi i mądrzy, którzy trzymają się Bożych praw i żyją wg nakazanego w Objawieniu modelu.

Dlaczego autor Mdr przewartościował wymowę faktów na korzyść Izraelitów?

Możliwe są trzy motywacje, łączące się ze sobą:

— pedagogiczna — dać egzemplum dobrego życia, któremu błogosławi Bóg;

— doksologiczno-apologetyczna — bronić Izraelitów przed antyżydowską ideologią oraz ściśle z tym związana następna motywacja;

- patriotyczna - wychwalać lud Pana.

Komponowanie i kompilacja źródeł służy oryginalnej syntezie. W tym procesie niejednokrotnie nie krępuje się istotnym dla historiografa chronologicznym porządkiem (por. 11, 3; 16, 18). W tej procedurze dominują niektóre metody:

- Hagiograf zestawia fakty opierając się na schemacie kazualnym. W tym celu wprowadza temat objaśniający, który pokazuje, że człowiek jest karany narzę- 
dziem własnego grzechu $(11,16)$ i ilustruje go 7 egzemplami. Np. w dyptychu I (11, 1-14) czytamy, że odwet za topienie izraelskich niemowląt w Nilu, wody rzeki zostały zamienione w krew, II dyptych $(16,1-4)$ pladze żab przeciwstawia dar przepiórek: czciciele zwierząt ściągnęli na siebie karę w postaci żab, w III dyptychu $(16,5-14)$ bałwochwalczy kult zwierząt spowodował karę szarańczy; IV dyptych (16, 15-29) ukazuje, że plaga żywiołów jest karą za ich ubóstwianie; antyteza o ciemności i świetle $(17,1-18,4)$ uczy, że ciemność jest następstwem ujarzmienia Izraelitów, przez których świat miał otrzymać niezniszczalne światło prawa $(18,4)$; w VI przeciwstawieniu $(18,5-25)$ śmierć pierworodnych Egipcjan jest przyczynowo powiązana z mordowaniem dzieci hebrajskich $(18,5)$; analogicznie śmierć wojska egipskiego w wodach Morza Czerwonego (19, 1-17).

- Mdr symultanicznie zestawia różne wydarzenia, tak jakby one miały miejsce w tym samym czasie, np. odrębne plagi zwierząt (16, 1. 9. 15-19). Kiedy opisuje klęskę gradu, też wspomina plagi zwierząt jakby były jednoczesne $(16,18)$.

- Zestawia dane rozproszone w Biblii, by uzyskać syntetyczny obraz postaci czy wydarzenia. Np. komponuje wizerunek magów egipskich ze stosownych wzmianek z Wj i umiejscawia ten obraz w innym niż Pięcioksięgu kontekście w dziewiątej pladze ciemności (17, 7a).

Analiza stosowania powyższych metod przez Autora Księgi Mądrości pozwala na wysunięcie następujących wniosków:

- zastosowanie procedury służy udowodnieniu doktryny teologicznej o retrybucji $(11,6-7 ; 16,1 ; 18,5)$;

— fakty pełnią funkcję egzemplów $(16,1.9 .15-19)$;

- posłużenie się biblijnym i pozabiblijnym materiałem pomaga lepiej zrozumieć tekst (18, 6-9), a zatem odpowiada na kompetencję odbiorców.

6. Przeciwstawienie materiałów różnych wydarzeń i opowiadań służy zilustrowaniu zasady ,ta sama rzecz może być narzędziem nagrody lub kary” $(11,5)$. Np. w I antytezie (11, 1-14) narzędziem nagrody i kary jest woda, w II antytezie $(16,1-4)$ narzędziem błogosławieństwa i przekleństwa są zwierzęta, w III antytezie $(16,5-14)$ motyw niosącej poganom śmierć szarańczy przeciwstawia mędrzec motyw jadowitych wężów bezskutecznie atakujących Izraelitów; przedmiotem IV antytezy $(16,15-29)$ jest ukazanie odmiennego działania żywiołów: siły przyrody same z siebie neutralne, aktywizują się w zależności od wewnętrznej postawy człowieka względem Boga, mianowicie bałwochwalcom niszczą płody ziemi, czcicielom Jahwe zaś — dają pokarm, mannę; V antyteza $(17,1$ - 18, 4) obejmuje plagę ciemności i słup obłoku; VI antytezie $(18,5-25)$ zagładę pierworodnych Egipcjan i ocalenie Izraelitów podczas nocy paschalnej; w VII antytezie (19, 1-17) żywioł — morze, staje się środkiem ocalenia dla Izraelitów i zagłady dla pogan. 
7. Uogólnienie cech jednostek stanowi przeciwieństwo historiograficznych tradycji. Autor $\mathrm{Wj}$ koncentruje uwagę na indywidualnościach (Mojżesz — faraon), które reprezentują grupy. W Mdr miejsce konfrontacji Mojżesz - faraon, zajmuje przeciwstawienie Izraelici - Egipcjanie; dobrzy — źli, sprawiedliwi — niesprawiedliwi, uciskani - ciemięzcy. Hagiograf traktuje bowiem biblijne opowiadanie o Wyjściu jako zbiór typów i parenetyczny paradygmat o uniwersalnym charakterze. Widać w tym także element moralnej zachęty.

Podobnemu jak wyżej celowi służy wydobywanie symbolicznego znaczenia $\mathrm{z}$ wydarzeń i rzeczy. Autor Mdr usiłuje odkryć w nich uniwersalne zasady. Np. $\mathrm{z}$ ww. 16, 28-29 wyprowadza wniosek o potrzebie rannej modlitwy i o niewdzięczności ludzkiej natury za dar manny. W w. 18, 24 interpretuje efod Aarona jako reprezentujący cały świat. Uczy też, że Bóg wynosi swój lud - obecnie jak i w przeszłości - do takiego wniosku dochodzi na podstawie rozważań przekazu 19, 22. Ta technika wydaje się wskazywać, że Mdr zamierzał skonstruować sobie współczesnych, o swojej doktrynie za pomocą biblijnej interpretacji. Pismo Święte pełni w niej rolę argumentu $\mathrm{z}$ autorytetu.

Stosuje także zabieg przesadni, która jest realizowana przez rozszerzenie prostego stwierdzenia, wyolbrzymienie wydarzenia czy kontrastu. Np. w ww. 19, 1317 manipuluje opisem grzeszności Egipcjan, przeciwstawiając ich znanym z deprawacji moralnej Sodomitom. Owa technika posługiwania się znanym z tradycji materiałem została podporządkowana przez hagiografa jej perswazyjnemu zamysłowi.

Interpretacja wydarzeń i treści Wyjścia dokonana przez autora Sophia Salomonos ujawnia następujące teologiczne tendencje:

1) Bóg orędownik i obrońca sprawiedliwych, zwraca się przeciw grzesznikom. Surowsze potraktowanie tych ostatnich ma cele pedagogiczne, mianowicie ma doprowadzić grzeszników do pokuty i nawrócenia.

2) Czasowo ograniczone cierpienia sprawiedliwych służą pouczeniu tak dobrych, jak i złych.

3) Kosmos rozumiany jako instrument Stwórcy wykorzystywany dla dobra sprawiedliwych i dla kary grzeszników.

Analiza filologiczna, szczególnie zwrócenie uwagi na tak ważne terminy jak diagnosis (Mdr 3, 18), kratesis $(6,3)$, threskeia $(14,18)$, sebasma $(14,2)$, oraz misoksenia $(19,13)$ oraz udana próba rekonstrukcji powstania przeciw Żydom w Aleksandrii prowadzi S. Choena do ostrożnego wniosku, że Księga Mądrości według wszelkiego prawdopodobieństwa powstała ok. r. 40 po Chr. za panowania cezara Kaliguli jako odpowiedź na cierpienia wspólnoty aleksandryjskiej. Wyjście Izraelitów z niewoli egipskiej w interpretacji Księgi Mądrości służy zamanifestowaniu ciągle aktualnego działania Boga w historii wzywającego człowieka do wia- 
ry oraz stanowi najdojrzalszy na gruncie Starego Przymierza etap rozwoju biblijnej idei Wyjścia. Hagiograf przewartościował historię Wyjścia w dzieje konfliktu dobrych ze złymi, dając poglądową naukę o Bożej Opatrzności.

Poznań

KS. BOGDAN PONIŻY

\section{KS. JACEK KUCHARSKI, Spocząć ze swymi przodkami, Lublin 1998, Wydawnictwo KUL, s. 196}

Opublikowana przez Wydawnictwo KUL rozprawa ks. Jacka Kucharskiego Spocząć ze swymi przodkami uzupełniła lukę w polskiej literaturze z zakresu zwyczajów, kultu i kultury izraelskiej oraz rzuciła światło na funeralne zwyczaje opisywane na kartach Pisma Świętego. Stało się to dlatego, jak pisze Autor we wstępie: „Człowiek jest niemal przekonany o istnieniu życia pozagrobowego, które będąc dla niego może jeszcze odległą perspektywą, jest postrzegane zarazem jako tajemnica, przeniknięta ogromnym szacunkiem [...]. Podstawową formą oddawania czci zmarłym było i jest grzebanie ciał, powiązane z obrzędem o charakterze religijnym, które niejednokrotnie posiada specjalne prawa. Ceremonie pogrzebowe są zjawiskiem powszechnym" (s. 9).

Publikacja złożona jest ze wstępu i czterech rozdziałów. We Wstępie Autor zaanonsował: „Przy analizie tekstów NT mówiących o grzebaniu zmarłych obok wykopalisk archeologicznych jest uwzględniona również wczesna tradycja rabinistyczna zawarta w Misznie, którą jeden ze znawców określił jako zbiór czterowiekowej tradycji religijnej judaizmu, panującej w Palestynie począwszy od połowy II wieku przed Chr. do II w. po Chr. oraz prawodawstwo wyrażone w innych częściach Talmudu" (s. 13).

Autor rozważania rozpoczął od charakterystyki wierzeń i wynikających z nich zwyczajów funeralnych Starożytnego Wschodu: Mezopotamii, Egiptu, Syrii i Palestyny. Zrobił to dlatego, gdyż zwyczaje pogrzebowe Izraelitów miały wiele wspólnych elementów z tymi zwyczajami u innych starożytnych narodów. Analizując zebrany materiał badawczy ukazał rozwój praktyk pogrzebowych oraz ich wspólne źródła. Przy tym przekazał wiadomości o kulcie zmarłych, zabytkach sakralnych i grobach $\mathrm{z}$ różnych środowisk tych czasów. Wykorzystał w rozprawie wyniki badań archeologicznych na terenie Palestyny, opublikowane w pracach R. de Vaux, A. G. Barroisa, S. Mędali, S. Gądeckiego i wielu innych.

Drugi rozdział poświęcony został zwyczajom izraelskim w oparciu o przekaz Starego Testamentu, ale także przy wykorzystaniu przekazów pozabiblijnych. Znalazły tu swoją analizę nie tylko obrzędowość pogrzebowa występująca u Izraelitów, czynności przygotowawcze do pogrzebu, grobu, żałobnych rytów, ale również informacje dotyczące postów i przepisów pokarmowych oraz żałobnego lamentu. 